\title{
Development of a low commercial value fish-sausage from the fish trawling "mix" category
}

\author{
Juliana de Lima Brandão GUIMARÃES ${ }^{1,2 *}$, Flávia Aline Andrade CALIXTO$^{1}$, Luiz Antônio de Moura KELLER², \\ Licínio Esmeraldo da SILVA ${ }^{3}$, Ângela Aparecida Lemos FURTADO ${ }^{4}$, Eliana de Fátima Marques de MESQUITA²
}

\begin{abstract}
The decreasing stock of the main species consumed in Brazil has stimulated studies regarding the use and development of products using low commercial value species. The shrimp trawling modality produces a large volume of a "mix" category comprising low commercial value fish. However, it is necessary to develop products with greater practicality to meet the current demands of the Brazilian consumer. The aim of the present study was to develop a sausage using a low commercial value fish, the Brazilian flathead (Percophis brasiliensis), caught in the fish trawling "mix" category landed in Niterói/RJ, and perform physico-chemical, microbiological, toxicological and sensorial analyses. The centesimal composition of the analyzed fish were as follows: humidity $73.78 \%$, proteins $16.17 \%$, carbohydrates $3.75 \%$, total lipids $4.41 \%$ and ash $1.78 \%$. The microbiological and toxicological results were within the legislation standards. Twenty varieties of fatty acids (AG) were detected, with the most frequent being palmitic acid (22.81\%). Among the omega-3 series, the most frequent were eicosapentaenoic acid (5.36\%) and docosahexaenoic acid (15.95\%). Regarding minerals, the most noteworthy were sodium, calcium and iron (1114.24 mg, $112.32 \mathrm{mg}$ and $1.73 \mathrm{mg}$ respectively). The sausage showed $87.30 \%$ acceptability. The results demonstrate that the low commercial value fish Brazilian flathead resulted in a viable product for use in fish technology, with excellent nutritional results.
\end{abstract}

Keywords: acceptability; bacteriological analyses; physico-chemical analyses; fish derivatives; accompanying fauna.

Practical Aplication: The developed sausage showed excellent quality.

\section{Introduction}

Due to the low selectivity and the small mesh sizes of the traditional nets, shrimp trawling has become responsible for the largest catches of accompanying fauna among all fishing modalities in the world. Part of the species caught as accompanying fauna are selected and marketed in the "mix" category, basically composed of low value species and some small, commercially important, species (Castro \& Yamaguti, 2000). The volume of the "mix" category is significant, since it has become an alternative to improve the value of trawling fisheries, due to the depletion of marine fish stocks (Perez et al., 2010).

Fishery Brazilian production has, increasingly, presented smaller stocks each year, bringing uncertainty to processors and wholesalers. The raw material often does not appear in the desired quantity and quality (Kubitza, 2007). Canned sardines, for example, from 2002 to 2012 showed approximately a $94 \%$ increase in imports in Brazil due to the decreasing stocks of this resource (Martins et al., 2016). Therefore, the use of low economic value fish species has been the subject of research in Brazil. Pires et al. (2014), showed the potential in the use of fish of the accompanying fauna in the development of products such as mechanically separated meat (MSM) and Surimi.
Commercial, low-value, fish species have been used as raw material in the production of mechanically separated meat (MSM), surimi and sausages (Tenuta-Filho \& Jesus, 2003). These technologies are employed for the use of solid fish waste mainly destined for animal feed, but which can also be used for the production of fertilizers or chemical products (Cavalcante et al., 2005). However, the nutritional value of these residues, rich in proteins and omega- 3 and omega- 6 fatty acids, encourages the full use of fish for the development of products destined for human consumption (Feltes et al., 2010).

Polyunsaturated fatty acids (PUFAs) with 18 to 22 carbons make up omega- 3 (w-3 or n-3) and omega- 6 (w-6 or $n-6)$. The major n-6 fatty acids are 18:2 linoleic acid and 20:4 arachidonic acid, and the major n-3 fatty acids are linolenic acid 18:3, eicosapentaenoic acid (EPA) 20:5 and docosahexaenoic acid (DHA) 22:6. Linoleic acid and $\alpha$-linolenic acid are essential fatty acids (EFAs) because the double bonds located on the third and sixth carbon atoms cannot be produced by the human body. Thus, essential fatty acids must be obtained from the diet (Martin et al., 2006). 
A-linolenic acid is converted to eicosapentaenoic acid-EPA and docosahexaenoic acid-DHA. However, the conversion rate is considered to be very low in humans, and, because this compound competes for the same enzyme system as linoleic acid, it tends to decrease as the amount of this acid increases. Therefore, it is of fundamental importance to obtain n-3 sources through food intake (Food and Agriculture Organization, 1994).

The presence of n-3 fatty acids, mainly EPA and DHA, in fish-containing diets and their by-products, has been related to beneficial health effects (Guiné \& Henriques, 2011). Among the physiological effects in humans, are the preventionand treatment of various types of cancer, cardiovascular diseases, hypertension, inflammation in general, asthma, arthritis and psoriasis (Mayser et al., 1998). Therefore, regardless of the market value of the captured species and the technology used for the development of derived products, the presence of dietary fish is essential in increasing the intake of the essential fatty acids so important for human health.

Despite proven nutritional quality, fish consumption in Brazil is still considered low (Brasil, 2011). This is explained by problems in distribution and marketing, and also by the absence of consumption habits, caused by the lack of practicality in fish preparation (Bonacina \& Queiroz, 2007). There is also a deficiency of products on the market to meet consumer demands resulting from an urban lifestyle, and it is increasingly necessary to offer ready or semi-ready products that are easy and quick to prepare (Battistella, 2008). However, in order to produce fish-based products, quality control of fish health and the use of technologies that ensure product safety are required (Gonçalves, 2011).
Thus, the aim of this study was to develop Brazilian flathead (Percophis brasilensis) sausages, a species caught in the trawling "mix" category, and perform physico-chemical, microbiological, toxicological and sensorial analyses of the final product, in order to evaluate its adequacy for human consumption.

\section{Materials and methods}

Brazilian flathead samples were collected totaling $30 \mathrm{~kg}$. The fish were randonly collected,, already slaughtered, at the moment of landing on the quayside in the municipality of São Gonçalo (RJ) and transported in isothermal boxes containing ice to the laboratory of the Fundação Instituto de Pesca do Estado do Rio de Janeiro (FIPERJ). At the FIPERJ laboratory, the fish were washed under running water, ventrally cut to remove the viscera and the heads and fillets were then removed. The fillets and the filleting residue were packed separately in plastic bags and stored in a freezer at $-18^{\circ} \mathrm{C}$.

The fillets and filleting residues were transported in isothermal boxes to the Laboratório de Processamento de Pescado da Embrapa Agroindústria de Alimentos (CTAA/EMBRAPA). Processing was performed according to the flowchart displayed in Figure 1. Subsequently, sausage samples were evaluated regarding physicochemical, microbiological, toxicological and sensorial analyses.

For the MSM, the filleting residue (bone skeleton and skin) was processed in a fish MSM machine (Mec Fish Brazil). Subsequently, the MSM was weighed and the samples were stored until the analysis (Fogaça, 2009).

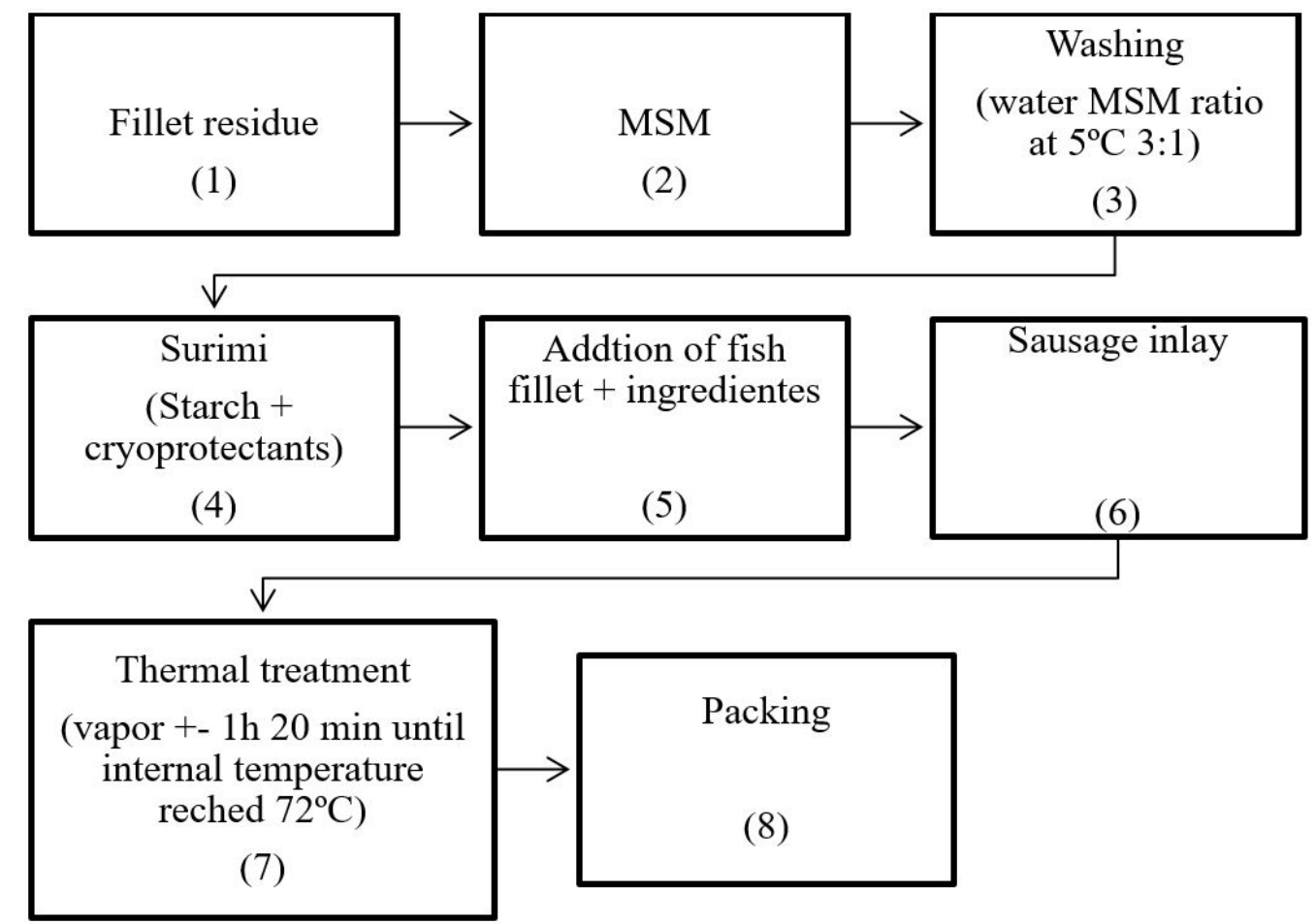

Figure 1. Flow diagram of the fish sausage process. 
Surimi was obtained by a wash cycle with water at $5^{\circ} \mathrm{C}$ at a 3:1 (water: meat) ratio. The water and MSM mixture was stirred for five minutes and then allowed to stand for two minutes. The excess water was removed with a 100 micrometer screen followed by a vacuum pump for five minutes. At the end of processing, starch (10\%) and cryoprotectants (2\% sodium chloride and $1 \%$ sucrose) were added to the mixture. The surimi was then weighed, and the samples collected and frozen $\left(-18^{\circ} \mathrm{C}\right)$ (Fogaça, 2009).

One sausage formulation ( $50 \%$ surimi $+35 \%$ fillet $+15 \%$ ingredients) was prepared. The surimi, fillet and ingredients were mixed in a cutter mixer (Geiger, model 50-, São Paulo, Brazil) for five minutes until an emulsion was obtained. After the emulsification process, the mixture was removed from the cutter mixer and brought to a manual filler using collagen casings. They were then tied at every $10 \mathrm{~cm}$ in length using cotton string.

The physical-chemical analyses performed on the samples were the following: pre-dried matter at $105^{\circ} \mathrm{C}$ (humidity); ashes; crude protein (MicroKjedahl) and ethereal extract (Soxlet method) (Brasil, 1981) for the determination of the centesimal composition. All samples were evaluated in triplicate at the Centro Estadual de Controle de Pesquisa em Qualidade de Alimentos (CEPQA), located in the Empresa de Pesquisa Agropecuária do Estado do Rio de Janeiro (PESAGRO-RJ). Carbohydrates (non-nitrogen extracted) were calculated by NIFEXT ("Nitrogen Free Extract"), by the difference between 100\% of the other fractions of the centesimal composition (Oliveira et al., 1999). The total energetic value (TEV) of the foods was calculated based on the carbohydrate, protein and lipid values, knowing that carbohydrates and proteins provide $4 \mathrm{kcal} / \mathrm{g}$ of energy and lipids, $9 \mathrm{kcal} / \mathrm{g}$ (Food and Agriculture Organization, 2005).

Fatty acid analyses were performed at the Laboratório de Óleos Graxos da Embrapa Agroindústria de Alimentos, according to the official Association of Official Analytical Chemists (2005) International method. Saturated and unsaturated fat content and weight/weight of each fatty acid were performed on the raw materials according to the official Association of Official Analytical Chemists (2005) International method. All samples were evaluated in triplicate.

The mineral profile analyses were performed at the Embrapa Food Technology, according to the methodology described by Association of Official Analytical Chemists (2005) International. All samples were evaluated in triplicate.

The microbiological analyses included Salmonella sp., coliform counts at $35^{\circ} \mathrm{C}$, thermotolerant coliforms and coagulase positive Staphylococcus. All analyses were performed according to methodology reported by the Ministério da Agricultura (Brasil, 2003a). All samples were evaluated in triplicate.

For the toxicological analyses, the presence of hydrogen sulphide gas $\left(\mathrm{H}_{2} \mathrm{~S}\right)$, was determined according to the technique described by Laboratório nacional de Referênca Animal (LANARA) (Brasil, 1981), while histamine content was determined according to the spectrophotometric methodology described by Glória \& Soares (1993). All samples were evaluated in triplicate.
The acceptance test of the final product was carried out at the Laboratório de Análise Sensorial da Faculdade de Veterinária at the Universidade Federal Fluminense (UFF) under the project "Acceptability of products developed with fish from the "mix" category from shrimp trawl fishery", approved by the Research Ethics Committee of the Faculty of Medicine/ Hospital Universitário Antônio Pedro - CEP CMM/HUAP no. 1,934,771 - CAAE n. 63083716.5.0000.5243.

The sausages were heated, in stages as per tasters' demand, in boiling water for two minutes, cut into two centimeter long pieces and served together with water at room temperature. All volunteers previously signed a free and informed consent form, guaranteeing their acceptance in participating in the test. The test was performed with untrained testers, UFF students and employees, of both genders. The acceptance test was performed according to Dutcosky's methodology (Dutcosky, 2011), in individual booths under white light and at room temperature.

The sensorial test was performed with 87 testers, who evaluated the product using a seven-point hedonic scale ( $1=$ very disagreeable, $2=$ moderately disliked, $3=$ mildly disliked, $4=$ didn't like or dislike, 5 = slightly liked, 6 = moderately liked; 7 = I liked it a lot) for odor, color, texture and flavor attributes and, finally, the overall aspect of the product. Observations could be written down by the tasters in the file itself. Finally, tasters were asked about their intention to buy the product divided into a five-point scale: I would definitely buy the product; probably buy; maybe yes/maybe not; I would probably not buy; I would decidedly not buy.

Regarding the results obtained by the hedonic scale method, the samples were accepted if $70 \%$ of the tasters assigned a score $\geq 4$.

\section{Results}

Table 1 expresses the results of the centesimal composition and the mineral profile of the Brazilian flathead product.

The main results of the lipid profile of the Brazilian flathead sausage are displayed in Table 2 .

Table 3 expresses the microbiological results of the Brazilian flathead (Percophis brasiliensis) product according to the Brazilian legislation.

Table 1. Mean results of the centesimal composition and mineral profile of the Brazilian flathead (Percophis brasiliensis) sausage.

\begin{tabular}{cr}
\hline Components & Values \\
\hline Humidity (\% $\left.{ }^{1}\right)$ & 73.78 \\
Protein (\%) & 16.17 \\
Lipids (\%) & 4.41 \\
Carbohydrates (\%) & 3.75 \\
Ashes (\%) & 1.89 \\
Energetic value $\left(\mathrm{kcal}^{2} 100 \mathrm{~g}^{-1}\right)$ & 119.37 \\
$\mathrm{Na}\left(\mathrm{mg} / 100 \mathrm{~g}^{3}\right)$ & 1114.24 \\
$\mathrm{Ca}(\mathrm{mg} / 100 \mathrm{~g})$ & 112.32 \\
$\mathrm{Fe}(\mathrm{mg} / 100 \mathrm{~g})$ & 1.73 \\
\hline
\end{tabular}

${ }^{1} \%$ = percentage; grams per hundred grams of food; ${ }^{2} \mathrm{kcal}=$ kilocalorie; ${ }^{3} \mathrm{mg} / 100 \mathrm{~g}=$ Milligrams per hundred grams of food. 
Sulfur-based compounds and histamine contents were evaluated for all sausage samples. None of these compounds were detected by the employed methodologies.

Regarding the sensory analysis, from the total of 87 tasters, $63.2 \%$ were female and $36.8 \%$ male, aged between 20 and 65 years old. The product was accepted at $87.3 \%$ for the overall product appearance, averaging $5.43( \pm 1.39)$. The acceptability results per attribute are listed in Table 4.

In the current study, regarding intention to buy the final product, the highest percentage of respondents attributed that they would probably buy it (34.5\%), followed by perhaps yes/maybe $(27.5 \%)$ and would decidedly buy the product $(21.8 \%)$, while $8.0 \%$ would probably not buy or would definitely not buy.

\section{Discussion}

The Brazilian legislation states that common sausages made with beef, pork or poultry must have the following chemical composition values: maximum humidity of $65 \%$, minimum protein content of $12 \%$ and maximum lipid content of $30 \%$ (Brasil, 2000). Therefore, according to the legislation, the produced Brazilian flathead sausage presented higher humidity values $(73.78 \%)$,

Table 2. Lipid profile and fatty acid quality of the sausage Brazilian flathead (Percophis brasiliensis).

\begin{tabular}{cc}
\hline \multirow{2}{*}{ Fatty acid } & Sample \\
\cline { 2 - 2 } & Sausage $(\mathrm{g} / 100 \mathrm{~g}$ of fat $)$ \\
\hline $\mathrm{SFAs}^{1}$ & 33.97 \\
$\Sigma \mathrm{MUFAs}^{2}$ & 33.05 \\
$\Sigma \mathrm{PUFAs}$ & 28.11 \\
$\Sigma \mathrm{AG} \omega 3^{4}$ & 23.40 \\
$\Sigma \mathrm{AG} \omega 6^{5}$ & 1.97 \\
$\Sigma \mathrm{AG} \omega 6 / \omega 3^{6}$ & 0.08 \\
$\Sigma \mathrm{PUFAs} / \Sigma \mathrm{SFAs}^{7}$ & 0.82 \\
\hline
\end{tabular}

${ }^{1} \Sigma$ SFAs $=$ sum of saturated fatty acids; ${ }^{2} \Sigma$ MUFAs = sum of monounsaturated fatty acids; ${ }^{3} \Sigma$ PUFAs $=$ sum of polyunsaturated fatty acids; ${ }^{4} \Sigma \mathrm{AG} \omega 3=$ sum of omega -3 fatty acids; ${ }^{5} \Sigma \mathrm{AG} \omega 6$ = sum of omega- 6 fatty acids; ${ }^{6} \Sigma \mathrm{AG} \omega 6 / \omega 3$ = ratio of the sum of omega- 6 fatty acids by the sum of omega- 3 fatty acids; ${ }^{7} \Sigma$ PUFAs $/ \Sigma$ SFAs $=$ ratio of the sum of polyunsaturated fatty acids by the sum of saturated fatty acids.

Table 3. Microbiological results of the Brazilian flathead (Percophis brasiliensis) product according to the Brazilian legislation (Brasil, 2003a).

\begin{tabular}{lcccc}
\hline Product & $\begin{array}{c}\text { Salmonella } \\
\text { sp. }\end{array}$ & $\begin{array}{c}\text { Coliforms } \\
\text { at } 35^{\circ} \mathrm{C}\end{array}$ & $\begin{array}{c}\text { Thermotolerant } \\
\text { coliform }\end{array}$ & $\begin{array}{c}\text { Positive } \\
\text { coagulase } \\
\text { Staphylococci }\end{array}$ \\
\hline Sausage & absent $/ 25 \mathrm{~g}^{1}$ & $<10 \mathrm{CFU} / \mathrm{g}^{2}$ & $<10 \mathrm{CFU} / \mathrm{g}$ & $<10^{2} \mathrm{CFU} / \mathrm{g}$ \\
\hline $\begin{array}{l}{ }^{1} \mathrm{Absent} / 25 \mathrm{~g}=\text { absent in twenty-five grams of food; }{ }^{2} \mathrm{CFU} / \mathrm{g}=\text { colony forming unit per } \\
\text { gram of food. }\end{array}$
\end{tabular}

Table 4. Mean values of the scores of each attribute in the sensorial analysis.

\begin{tabular}{ccccc}
\hline Attribute & Taste & Odor & Texture & Color \\
\hline $\begin{array}{l}\text { Means } \\
( \pm \text { s.d. })\end{array}$ & $5.6( \pm 1.43)^{\mathrm{a}}$ & $5.5( \pm 1.16)^{\mathrm{a}}$ & $5.4( \pm 1.6)^{\mathrm{a}}$ & $4.8( \pm 1.76)^{\mathrm{b}}$ \\
\hline
\end{tabular}

Equal letters between different attributes indicate that the scores do not differ from each other. but met protein requirements $(16.17 \%)$. The humidity value above the recommended level can be explained by the absence of fats from other sources and the inherent characteristics of fish meat, resulting in a product with high humidity content, but lipid content well below the maximum limit recommended by the legislation. These results confirm the nutritional quality and the association of fish products with healthy diets.

Regarding protein levels, the levels of the present study were higher than those found by Gonçalves et al. (2009) in "piramutaba" (Brachyplatystoma vaillantii) sausage (12.6\%). Ribeiro et al. (2017), in a study in which kibbe and meatballs were baked from fish pulp obtained from the trawling "mix" category, found lower protein levels (kibbe: 15.10\%, meatball: 15.10\%) compared to the present study (16.17\%). When comparing the lipid results of this same study (kibbe: $4.50 \%$, meatball: $4.40 \%$ ), the Brazilian flathead sausage was similar (4.41\%), although higher than lipid content reported by Silva et al. (2012) in a study on the development of croaker sausage $(0.57 \%)$. On the other hand, the present study observed lower ash (1.89\%) contents when compared to Gonçalves et al. (2009), of 3.51\%. Such differences in results can be explained by the intrinsic characteristics of each species.

Regarding the nutritional requirements recommended by the Brazilian National Health Surveillance Agency (Brasil, 2003b), a $100 \mathrm{~g}$ portion of Brazilian flathead sausage would serve $5.9 \%$ of the recommended daily energy value and $21.56 \%$ of the daily requirement $(75 \mathrm{~g} /$ day) of crude protein, proving to be an alternative source of protein containing low calories, ideal for $2.000 \mathrm{kcal} /$ day diets. The $1,114.24 \mathrm{mg}$ of sodium in each $100 \mathrm{~g}$ portion would attend $46.43 \%$ of the daily necessities $(2.400 \mathrm{mg} /$ day $)$ of an adult individual, although more studies are necessary regarding the sausage formulation in order to create adjustments concerning this mineral. However, in a study in which the sodium content in hot dog meat sausages was evaluated, the average sodium content was of $551 \mathrm{mg}$ of sodium per $50 \mathrm{~g}$ portion (Brasil, 2010), in the same range as the results found herein.

$\Sigma$ SFAs content was $33.97 \%$, with palmitic acid (C16:0) being the most frequent (22.81\%). $\Sigma$ MUFAs were present at $33.05 \%$ with oleic acid, which is used in the body as a preferential source of metabolizable energy during rapid growth (Menezes et al., 2009), at higher concentrations (20.85\%). $\Sigma$ PUFAs were present at $28.11 \%$, with $\Sigma A G \omega 3$ being more significant $(23.40 \%)$, with emphasis on EPA (5.36\%) and DHA acid (15.95\%). Saturated fatty acids are related to increased plasma cholesterol levels and may be related to the formation of atheroma plaques in the human body. On the other hand, EPA and DHA have received increased attention, since they reduce risk factors associated with cardiovascular diseases, hypertension, inflammation in general, asthma, arthritis, psoriasis and various types of cancer (Martin et al., 2006).

The relationship between omega 6 and omega 3 fatty acids $(\Sigma \omega-6 / \Sigma \omega-3)$ and the ratio of polyunsaturated to saturated acids ( $\Sigma$ PUFAs / $\Sigma$ SFAs) are used to establish lipid quality in the diet. Herein, $\Sigma \omega-6 / \Sigma \omega-3$ was of 0.08 , which is much higher than that usually consumed in the West, of 10-20:1 (Rêgo, 2012). According to data from the Department of Health and Social Security of 
England (Department of Health and Social Security, 1984), $\Sigma$ PUFAs/ $\Sigma$ SFAs should not be less than 0.45 , which translates into an unhealthy diet, mainly in relation to cardiovascular diseases. The Brazilian flathead sausage presented $\Sigma$ PUFAs $/ \Sigma$ SFAs of 0.82 , above dietary recommendations. Menezes et al. (2009), in a study that evaluated the fatty acid profile of two marine fish species from the Brazilian state of Alagoas, reported $\Sigma$ PUFAs/ $\Sigma$ SFAs for striped mojarra (Eugerres plumieri) and mackerel (Scomberomorus cavala) of 0.82 and 1.34 respectively, above the values found in the present study. However, the sum of EPA + DHA was of $15.32 \%$ for mackerel and $6.02 \%$ for the striped mojarra, below what was observed herein, of $21.31 \%$. Scherr et al. (2015), in a study that analyzed the $n-6 / n-3$ ratio in grilled fish comprising the main fish species consumed in Brazil, found lower results for all species (Sea bass (Dicentrarchus labrax), 0.34, Grouper (Epinephelus lanceolatus): 2.50, "Piraiba" (Brachyplathystoma filamentosum): 3.73, "Namorado Sandperch" (Peudopercis numida): 0.63, "Pescadinha"(Cynoscion acoupa): 5.98, "Pirarucu" (Arapaima gigas): 1.21, Common snook (Centropomus undecimalis): 0.34; Sardine (Sardinella brasiliensis): 0.60; Trout (Oncorhynchus mykiss): 4.03; Salmon (Salmo salar): 2.41) when compared to the results found in the present study.

The Agência Nacional de Vigilância Sanitária - ANVISA (Brasil, 2001) establishes a maximum permitted tolerance of fecal coliforms of $10^{2} \mathrm{CFU} / \mathrm{g}$ in refrigerated fish, the absence of Salmonella ssp.and maximum values of $<5 \times 10^{2} \mathrm{CFU} / \mathrm{g}$ for coagulase positive Staphylococcus. In the Brazilian flathead product, values lower than the limit determined by current legislation were found. Thus, the product was in accordance to established standards. Similarly to the results found in the present study, Galvão (2009), in a study conducted on "piramutaba" (Brachyplatystama vaillanti) sausage, found results in accordance to the legislation regarding coagulase positive staphylococcus.

The Brazilian legislation considers that fish belonging to the Scombridae, Scombresocidae, Clupeidae, Coryyphaenidae families (Brasil, 1997) with a positive reaction for sulfuric gas (Brasil, 2017) and with histamine levels above the maximum level of $100 \mathrm{ppm}$ in muscle are deteriorated. Studies to detect these quality and freshness indicators in fish have been developed, preferably, in fresh or frozen products In the current study, no histamine and sulfur compounds levels higher than those recommended by the legislation were detected. However, Souza et al. (2017), when evaluating the freshness of frozen marine fish, detected sulfide gas $\left(\mathrm{H}_{2} \mathrm{~S}\right)$ in $70.8 \%$ of the analyzed samples, indicating an advanced stage of decomposition. Soares et al. (1998), in a study analyzing frozen fish fillets, found histamine concentrations above the maximum permissible levels in $37 \%$ of the samples.

Reports of lesser acceptability of the final product than the current study (87.3\%) are available in the literature. Oliveira (2009), testing different tilapia sausage formulations, obtained an overall acceptability of $78.1 \%$, similar to Gonçalves et al. (2009), who obtained $75.6 \%$ overall acceptance regarding "piramutaba" sausage containing $30 \%$ shrimp flavor.

In a study on sausage elaboration with Nile tilapia mechanically separated meat (MSM), Lago (2015) evaluated odor, color, flavor and texture attributes obtaining $75.0 \%, 53.12 \%$ and $75.0 \%$ and $78.1 \%$ for each, respectively, all below the results found observed herein $(94 \% ; 72 \% ; 85 \%$ and $88 \%)$. Similarly to the results found in the present study, the color attribute was the least accepted and statistically different from the other attributes, possibly explained by the clear and unusual appearance of the sausages. For color, some opinions were registered in the current study that indicate the cause of low acceptance values in the present study, namely "very pale", "very clear", "pale" and "very opaque".

The purchase intention results of the present study were lower (34.5\% "problably buy it; $27.5 \%$ "perhaps yes/maybe") than in the study conducted by Lago (2015), who obtained a higher percentage in intention to buy on the second scale, "would probably buy", followed by the first scale, "would certainly buy", in a study on Nile tilapia sausage. In the present study, the highest percentages were attributed to the "would likely buy" option, followed by "maybe yes/no", but only $16.0 \%$ of the testers "decidedly" and "would probably not buy the product", indicating that the product would have excellent market acceptance.

\section{Conclusions}

The developed product, Brazilian flathead sausage, was shown to display satisfactory hygienic-sanitary conditions, good nutritional quality, with emphasis on polyunsaturated fatty acid content, and a high index of sensorial acceptance emphasizing odor and flavor, with excellent purchase intention Thus, fish that could be underutilized or even discarded proved to be a viable alternative for the development of a safe, versatile and nutritious consumer product.

\section{Acknowledgements}

The authors would like to thank CAPES for the PhD scholarship, to empoloyee Eduardo da Silva Machado (FIPERJ), to $\mathrm{PhD}$ candidate Karoline Ribeiro Palmeira Schmalz (UFF) and to FIPERJ extensionists FIPERJ Carlos Eduardo Ribeiro Coutinho and Bruno Plastina for analyses support.

\section{References}

Association of Official Analytical Chemists - AOAC. (2005). Official Methods of Analysis of the Association of Official Analytical Chemists (18th ed.). Gaithersburg, MA: AOAC International.

Battistella, P. M. D. (2008). Análise de sobrevivência aplicada à estimativa da vida de prateleira de salsicha. Retrieved from https://repositorio. ufsc.br/handle/123456789/92035

Bonacina, M., \& Queiroz, M. I. (2007). Elaboração de empanado a partir da corvina (Micropogonias furnieri). Food Science and Technology, 27(3), 544-552. http://dx.doi.org/10.1590/S0101-20612007000300019.

Brasil, Ministério da Agricultura, Pecuária e Abastecimento. Laboratório Nacional de Referência Animal - LANARA. (1981). Métodos analíticos oficiais para controle de produtos de origem animal e seus ingredientes (Vol. 2, Cap. 11). Brasília: LANARA.

Brasil, Ministério da Agricultura, Pecuária e Abastecimento. (1997, May 13). Aprova o Regulamento sobre Técnico de Identidade e Qualidade de Peixe Fresco (Inteiro e Eviscerado) e seus Anexos (Portaria ${ }^{\circ} 185$, de 13 de maio de 1997). Diário Oficial [da] República Federativa do Brasil.

Brasil, Ministério da Agricultura, Pecuária e Abastecimento. (2000, March 31). Aprovar os Regulamentos Técnicos de Identidade e 
Qualidade de Carne Mecanicamente Separada, de Mortadela, de Linguiça e de Salsicha. (Instrução Normativa ${ }^{\circ} 4$, de 31 de março de 2000). Diário Oficial [da] República Federativa do Brasil.

Brasil, Agência Nacional de Vigilância Sanitária - ANVISA. (2001, January 2). Padrão microbiológico para alimentos (Resolução $\mathrm{RDC}^{\circ}$ 12, de 2 de janeiro de 2001). Diário Oficial [da] República Federativa do Brasil.

Brasil. Ministério da Agricultura, Pecuária e Abastecimento. (2003a, August 26). Métodos analíticos oficiais para análises microbiológicas para o controle de produtos de origem animal e água (Instrução Normativa 62, de 26 de agosto de 2003). Diário Oficial [da] República Federativa do Brasil.

Brasil, Agência Nacional de Vigilância Sanitária - ANVISA. (2003b, December 23). Aprova Regulamento Técnico sobre Rotulagem Nutricional de Alimentos Embalados, tornando obrigatória a rotulagem nutricional (Resolução RDC n ${ }^{\circ} 360$ de 23 de dezembro de 2003. Diário Oficial [da] República Federativa do Brasil.

Brasil, Agência Nacional de Vigilância Sanitária - ANVISA. (2010). Perfil nutricional dos alimentos processados (Informe Técnico, Vol. 43, 52 p.). Brasília. Retrieved from: http://portal.anvisa.gov.br/ documents/33916/388729/Informe+T\%C3\%A9cnico+n\%C2\%BA+43 $\% 2 \mathrm{C}+\mathrm{de}+2012 / 7$ e593f1d-434a-421d-adaa-706fa042c06e?version $=1.1$

Brasil, Ministério da Pesca e Aquicultura. (2011). Boletim Estatístico da Pesca e Aquicultura 2010. Brasília: MPA. Retrieved from: http:// sinpesq.mpa.gov.br/preps_cms/index.php?option=com_content \& view $=$ article\&id $=21 \&$ Itemid $=27$

Brasil, Ministério da Agricultura, Pecuária e Abastecimento. (2017, March 29) Regulamenta a lei $n^{\circ} 1.283$, de 18 de dezembro de 1950, e a lei $\mathrm{n}^{\circ} 7.889$, de 23 de novembro de 1989, que dispõem sobre a inspeção industrial e sanitária de produtos de origem animal (Decreto no 9.013, de 29 de março de 2017). Diário Oficial [da] República Federativa do Brasil.

Castro, P. M. G., \& Yamaguti, N. (2000). Estrutura e dinâmica da frota de parelhas do Estado de São Paulo e aspectos biológicos dos principais recursos pesqueiros demersais costeiros da Região Sudeste/Sul do

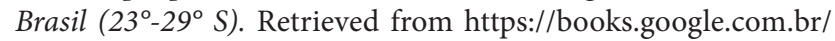
books/about/Estrutura_e_din\%C3\%A2mica_da_frota_de_parelh. html?id=MevNHAAACAAJ\&redir_esc=y

Cavalcante, V., Jr., Andrade, L. N., Bezerra, L. N., \& Gurjão, L. M. (2005). Reúso de água em um sistema integrado com peixes, sedimentação, ostras e macroalgas. Revista Brasileira de Engenharia Agrícola e Ambiental, 9(Suppl.), 118-122.

Department of Health and Social Security - DHSS. (1984). Diet and cardiovascular disease (Report on Health and Social Subjects, $\mathrm{N}^{\circ}$ 28). London: HMSO.

Dutcosky, S. D. (2011). Análise sensorial de alimentos. Curitiba: Editora Universitária Champagnat.

Feltes, M., Correia, J. F., Beirão, L. H., Block, J. M., Ninow, J. L., \& Spiller, V. R. (2010). Alternativas para a agregação de valor aos resíduos da industrialização de peixe. Revista Brasileira de Engenharia Agrícola e Ambiental-Agriambi, 14(6), 669-677. http://dx.doi.org/10.1590/ S1415-43662010000600014.

Fogaça, F. H. D. S. (2009). Caracterização do surimi de tilápia do Nilo: morfologia e propiedades físicas, químicas e sensoriais. Retrieved from https://alsafi.ead.unesp.br/handle/11449/100247

Food and Agriculture Organization - FAO, \& World Health Organization - WHO. (1994). Lipids in early development in fats and oil in human nutrition. Rome: FAO. Retrieved from http://www.fao.org/docrep/ v4700e/v4700e00.htm
Food and Agriculture Organization - FAO. (2005). The Codex Alimentarius Commission and the FAO/WHO Food Standards Programme. Special Publications. Food Labelling: complete texts. Retrieved from: http:// www.codexalimentarius.net/web/publications_es.jsp

Galvão, G. C. D. S. (2009). Influência dos Substitutos de Gordura na Salsicha de Pescado Elaborada com Resíduos da Filetagem da Piramutaba Brachyplatystama vaillanti (Valenciennes, 1840) (Dissertação de mestrado). Universidade Federal do Pará, Belém.

Glória, M. B. A., \& Soares, V. F. M. (1993). Comparison of fluorometric methods for the determination of histamine fish. Arquivos de Biologia e Tecnologia, 36(2), 229-235.

Gonçalves, A. A. (2011). Formatados e reestruturados (hambúrguer, nuggets etc.). In A. A. Gonçalves. Tecnologia do pescado: ciência, tecnologia, inovação e legislação (pp. 235-245). São Paulo: Atheneu.

Gonçalves, A. A., Nogueira, W. M., \& Lourenço, L. F. H. (2009). Aproveitamento do descarte do processamento da piramutaba (Brachyplatystoma vaillantii) e do camarão-rosa (Farfantepenaeus subtilis) na produção de salsicha sabor camarão. Boletim do Instituto de Pesca, 35(4), 623-635.

Guiné, R., \& Henriques, F. (2011). O papel dos ácidos gordos na nutrição humana e desenvolvimentos sobre o modo como influenciam a saúde. Millenium, 40, 7-21.

Kubitza, F. (2007). Percepções sobre a qualidade dos produtos de pescado. Retrieved from http://www.cca.ufc.br/Percep\%E7\%F5es\% 20Sobre\%20 a\%20Qualidade\%20dos\%20Pro dutos\%20de\%20Pescado.htmlca

Lago, A. M. T. (2015). Embutido tipo salsicha utilizando carne mecanicamente separada de tilápia: uma alternativa para o aproveitamento de resíduo da filetagem. Retrieved from http://repositorio.ufla.br/handle/1/10310

Martin, C. A., Almeida, V. V., Ruiz, M. R., Visentainer, J. E. L., Matshushita, M., Souza, N. E., \& Visentainer, J. V. (2006). Ácidos graxos poliinsaturados ômega-3 e ômega-6: importância e ocorrência em alimentos. Revista de Nutrição, 19(6), 761-770. http://dx.doi. org/10.1590/S1415-52732006000600011.

Martins, A. M. D., Cappato, L. P., Pacheco, S., \& Godoy, R. L. O. (2016). Sardinhas: importância nutricional e econômica para o Brasil. Semioses, 10(2), 51-59.

Mayser, P., Mrowietz, U., Arenberger, P., Bartak, P., Buchvald, J., Christophers, E., Jablonska, S., Salmhofer, W., Schill, W. B., Krämer, H. J., Schlotzer, E., Mayer, K., Seeger, W., \& Grimminger, F. (1998). $\omega-3$ Fatty acid-based lipid infusion in patients with chronic plaque psoriasis: results of a double-blind, randomized, placebo-controlled, multicenter trial. Journal of the American Academy of Dermatology, 38(4), 539-547. http://dx.doi.org/10.1016/S0190-9622(98)70114-8. PMid:9555791.

Menezes, M. E. D. S., Giselda, M. L., Omena, C. M. B. D., \& Freitas, J. D. D. (2009). Valor nutritivo de peixes da costa marítima de Alagoas, Brasil. Revista do Instituto Adolfo Lutz, 68(1), 21-28.

Oliveira, E. C. M., Oliveira, E. R., Lima, L. C. O., \& Boas, E. V. B. V. (1999). Composição centesimal do cogumelo do sol (Agaricus blazei). Revista da Universidade de Alfenas, 5, 169-172.

Oliveira, P. R., Fo. (2009). Elaboração de embutido cozido tipo salsicha com carne mecanicamente separada de resíduos de filetagem de tilápias do Nilo. Retrieved from https://repositorio.unesp.br/bitstream/ handle/11449/100241/oliveirafilho_prc_dr_jabo.pdf?sequence=1

Perez, J. A., Pezzuto, P. R., Rodrigues, L. F., Valentini, H., \& Vooren, C. M. (2010). Relatório da reunião técnica de ordenamento da pesca de arrasto nas regiões sudeste e sul do Brasil. Notas Técnicas da FACIMAR, 5, 1-34. http://dx.doi.org/10.14210/bjast.v5n1.p1-34.

Pires, D. R., Silva, P. P. O., Amorim, E., \& Oliveira, G. M. (2014). Espécies de pescado subexplotadas e seu potencial para elaboração 
de subprodutos com valor agregado. Revista Verde de Agroecologia e Desenvolvimento Sustentável, 8(5), 148-157.

Rêgo, F. L. T. (2012). Estudo do perfil de ácidos graxos e a razão entre ômega 6/ômega 3 em pescado. Retrieved from https://repositorio. ufba.br/ri/handle/ri/11594

Ribeiro, D. S., Calixto, F. A. A., Guimarães, J. L. B., Aronovich, M., Keller, L. A. M., \& Mesquita, E. F. M. (2017). Produtos de pescado elaborados com resíduos de arrasto: análise físico-química, microbiológica e toxicológica. Arquivo Brasileiro de Medicina Veterinária e Zootecnia, 70(1), 238-246. http://dx.doi.org/10.1590/1678-4162-8940.

Scherr, C., Gagliardi, A. C. M., Miname, M. H., \& Santos, R. D. (2015). Concentração de ácidos graxos e colesterol de peixes habitualmente consumidos no Brasil. Arquivos Brasileiros de Cardiologia, 104(2), 152-158. PMid:25424160.

Silva, G. P. R., Palezi, S. C., Kubota, E. H., \& Maran, M. H. D. S. (2012). Embutido emulsionado com adição de isolado proteico à base de pescado (Micropogonias furnieri). Unoesc e Ciência-ACET, 3(2), 179-186.

Soares, V. F., Vale, S. R., Junqueira, R. G., \& Glória, M. B. A. (1998). Teores de histamina e qualidade físico-química e sensorial de filé de peixe congelado. Food Science and Technology, 18(4), 462-470. http://dx.doi.org/10.1590/S0101-20611998000400020.

Souza, M. M. M., Nóbrega, F. D. M., Cardoso, R. D. C. V., Argôlo, S. V., Silva, Í. R. C., \& Santos, L. F. P. (2017). Avaliação do frescor do pescado congelado comercializado no mercado municipal de São Francisco do Conde-BA. Boletim do Instituto de Pesca, 39(4), 359-368.

Tenuta-Filho, A., \& Jesus, R. S. (2003). Aspectos da utilização de carne mecanicamente separada de pescado como matéria-prima industrial. Boletim da Sociedade Brasileira de Ciência e Tecnologia de Alimentos, 37(2), 59-64. 